\title{
Design of New Student Registration Information System at MTsN 4 Kab. Lima Puluh Kota Android Based Cities
}

\author{
Yulia Elsa Putri ${ }^{1, *}$, Sarwo Derta ${ }^{2}$ \\ 1,2Informatics and Computer Engineering Education IAIN Bukittinggi, Bukittinggi, Indonesia
}

\begin{tabular}{l} 
Article Information \\
\hline Article History: \\
Accepted by Editor: November 06, 2021 \\
Final Revision: November 24, 2021 \\
Published Online: December 31, 2021 \\
Keywords \\
\hline Information Systems \\
Android \\
R\&D \\
4 D \\
Waterfall \\
Correspondence
\end{tabular}

E-mail: yuliaelsa.putri01@gmail.com*

\begin{abstract}
A B S T R A C T
There are still not many SMP/MTs/Equivalents in Indonesia holding online New Student Admissions, one example being MTsN 4 Kab. Lima Puluh Kota under the auspices of the Ministry of Religion Kab. Lima Puluh Kota. During manual PPDB at MTsN 4 Kab. Lima Puluh Kota there are several obstacles both experienced by the school, prospective students and parents, both in terms of administration or information at the time of PPDB implementation. Another problem that arises is the distance of the radius and distance of students who will register to school; from the data, the authors found that the radius and the furthest distance traveled by students was $\pm 18-20$. It is the author's background in designing an Android-based PPDB information system using the $4 \mathrm{D}$ version of the R\&D method with the SDLC waterfall system development model. The programming language used is PHP language assisted with MySQL database. From the product test that the author did, the results obtained: the validity test was carried out by filling out a questionnaire that referred to the Aiken's V statistical formula, namely 0.80 Valid criteria addressed to 3 lecturers, the practicality test was carried out by filling out a questionnaire which was analyzed with a percentage per rhythm, namely 93,33 Very Practical criteria aimed at 3 teachers and the effectiveness test is carried out by filling out a questionnaire that refers to the statistical moment kappa formula, namely 0.91 Very Effective criteria addressed to 15 students.
\end{abstract}

This is an open access article under the CC-BY-SA license

\section{Introduction}

There are still many SMP/MTs/Equivalents in Indonesia that have not implemented online New Student Admission, one example is MTsN 4 Kab. Lima Puluh Kota under the auspices of the Ministry of Religion Kab. Lima Puluh Kota. Utilizing the development system in the current digital era will make it easier for schools to distribute information. It is following advances in Android-based technology using WhatsApp Autorespond which can quickly support the input and output process and accurately and Autorespond without having to wait long, especially in implementing new student admissions.

There has been research on PPDB, namely Thesis from Yanti Maryani, Informatics and Computer Engineering Education Study Program, Faculty of Tarbiyah and Teacher Training, IAIN Bukittinggi (Designing Information System for Admission of New Students Online at MTI Canduang Using JavaScript and PHP/MySQL Programming Languages. [1] Furthermore, Thesis Rahmatillah, Informatics and Computer Engineering Education Study Program, Faculty of Tarbiyah and Teacher Training, IAIN 
Bukittinggi (Designing Information System for Bari Student Admissions at MA Kauman Padang Panjang Using PHP/MySQL. However, the system is not yet based on Android.

Information Technology According to UU ITE no. 11 of 2008 Article 1, Paragraph 3 is a technique of collecting, preparing, storing, processing, publishing, analyzing and disseminating information. [2] The term "information technology" has been used since the 1980s. Technology is the development of computer technology combined with telecommunications technology. the term "information" is agreed as "the result of data processing," which in principle has more value that can be compared with raw data. [2] Admission of new students at the junior high school level is carried out online, preferably children aged 12-15 years as stated in Permendikbud No. 17 of 2017. [3]

Education is the right of everyone to play an essential role in the life of the nation and state. Implementing this education is useful for educating and developing the nation's morals to become more dignified. Education is an important thing so that it can help the government improve education services. [4]

During the acceptance of manual registration at MTsN 4 Kab. Lima Puluh Kota has several obstacles both experienced by schools, prospective students and parents, both in terms of administration or information during PPDB implementation, resulting in less efficient use of time, place, cost and energy required. Misinformation received by prospective students from the brochures distributed and parents' understanding of the information contained in the brochures resulted in errors. The amount of time needed for prospective students to complete the requirements according to the criteria proposed by the school. In terms of administration, file submission errors often occur due to misunderstandings in writing information on brochures. Therefore, the author wants to design an online PPDB information system to facilitate the registration process while still using brochures and accompanied by online information services.

At the time of receipt of manual registration at MTsN 4 Kab. Lima Puluh Kota, another problem that arises is the distance and radius of the students who will register, from the data that the authors have found, the radius and the farthest distance traveled by prospective students is $\pm 18-20 \mathrm{~km}$, which is in Nagari Halaban, Sei. Ipuh and Sei. Kamuyang. Students who are interested in MTsN 4 Kab. Lima Puluh Kota are many areas outside the school location because of MTsN 4 Kab. Lima Puluh Kota has been classified as advanced and have achieved various kinds of achievements so that there are many enthusiasts. For this reason, many students flocked to enter MTsN 4 Kab. Lima Puluh Kota, but to find information for these prospective students requires a very long distance.

Parents must also be involved in obtaining information because it is not possible for prospective students who are far away to go to school alone and still have to be in the area of their respective parents. It is disturbing in terms of their parents' work, the average livelihood of parents of prospective students at MTsN 4 Kab. These Lima Puluh Kota are farm laborers whose daily net income is \pm Rp. 35,000, for example parents accompanying their children to school to see registration information only, will lose their opinion that day.

In order to fix the PPDB process and services to prospective students, it is necessary to have a system that can carry out the PPDB process without limits - one of them by utilizing Android-based technology. The Android-based PPDB Information System is expected to make it easier for prospective students to obtain information. So that prospective students can obtain information without having to go to school.

MTsN 4 Kab. Lima Puluh Kota is State Madrasah Tsanawiyah which previously tried to use technological developments using the Website due to the lack of expertise in MTsN 4 Kab. Lima Puluh Kota so that the Website will not be run. In welcoming the new school year for prospective students, other reference schools are already using online registration.

Based on the explanation above, the author took the initiative to design an Android-based PPDB information system where first the author will design a school website which is then synchronized via WhatsApp Autorespond. This system can make it easier for the new student admissions committee to 
process PPDB implementation. Conclusion and make it easier for prospective students in the registration process to monitor information related to PPDB from any location and at any time via a smartphone connected to the internet network.

\section{Method}

The author's research method is $R \& D$, a research method used to create a product and carry out product trials [5]. Research and Development is a process to produce quality new products [6].

This study aims to design a product in the form of an Android-based PPDB information system implemented in MTsN 4 Kab. Lima Puluh Kota. The selected R\&D research step is the 4D version. The 4D model consists of four stages as shown in Figure 1.

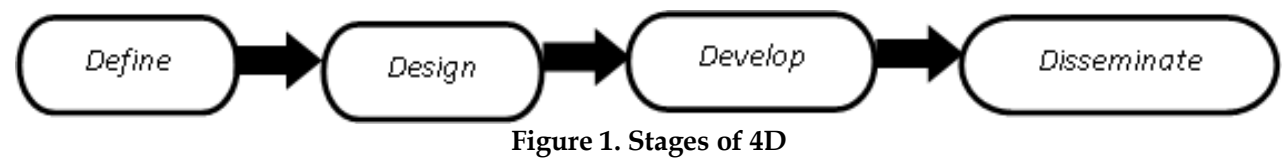

The activities carried out at each stage of development [6], namely define is the initial process of research, namely collecting and describing system problems to be designed and specifications to be developed. The second stage is design, namely product description. The third stage is development, namely product design and product testing. The final stage is dissemination, which is the dissemination of products that have been tested and can be used by many people. [7]

Product test consists of validity test, practicality test, and effectiveness test. The instrument used is a questionnaire.

\subsection{Validity Test}

The product validity test was conducted to determine the level of validity of the instrument used. An instrument is valid if it can measure what is desired and can reveal data from the variables studied appropriately. The validity test is carried out with expert validity, validating the product to experts in terms of content, design and logic. [8] To produce a quality product, it is necessary to test the validity of the product. Several experts carried out the validity test. Testing is done by filling out a questionnaire. The validity test is carried out by referring to Aiken's V statistical formula. The formula is as in equation (1) below [5].

$$
V=\sum \frac{s}{n(c-1)}
$$

$$
\begin{aligned}
& \text { Description : } \\
& V=\text { Validity test } \\
& S=r-l o \\
& r=\text { the number given by the rater } \\
& l o=\text { lowest validity research numbers } \\
& n=\text { number of appraisers } \\
& C=\text { the highest number of validity research }
\end{aligned}
$$

The value of the validity criteria can be seen in table 1 . 
Table 1. Criteria for Determining Validity [5]

\begin{tabular}{cc}
\hline Percentage $\%$ & Criteria \\
\hline $0,6<$ & Invalid \\
$>=0,6$ & Valid \\
\hline
\end{tabular}

\subsection{Practical Test}

The practical aspect is the result of user or user research. The data from the practicality test were analyzed by percentage per rhythm, as in equation (2) below [5].

$$
P=\frac{(\Sigma f)}{N} \times 100 \%(2)
$$

Description:

$P=$ final score

$f=$ score

$N=$ maximum score

\subsection{Effectiveness Test}

The effectiveness test is the last stage in product testing. The effectiveness test is a measurement of the suitability of the product results to the initial goal. The effectiveness test is carried out by referring to the moment kappa statistical formula, as in equation (3) below [5] :

$$
k=(\rho-\rho e) /(1-\rho e)
$$

Description:

$K=$ product effectiveness

$\rho=$ realized proportion

$$
\rho e=\text { unrealized proportion }
$$

\section{Results and Discussion}

\subsection{Define}

The elaboration of a problem that arises in the design of information systems. Based on research that has been carried out at MTsN 4 Kab. Lima Puluh Kota, it turns out that the problem that arises is the difficulty of the registration process, administration, and obtaining information on the implementation of manual PPDB. And less efficient radius and distance from home to school.

\subsection{Design}

At this stage, the author describes the flow of information systems according to the needs of system and system users and to whom this information system is intended. Here the author creates an admin flowchart system and a user flowchart system.

\subsection{Develop}

\subsubsection{General System Design}

a) Use case diagram

Figure 2 is a use case diagram of the new student registration information system. 


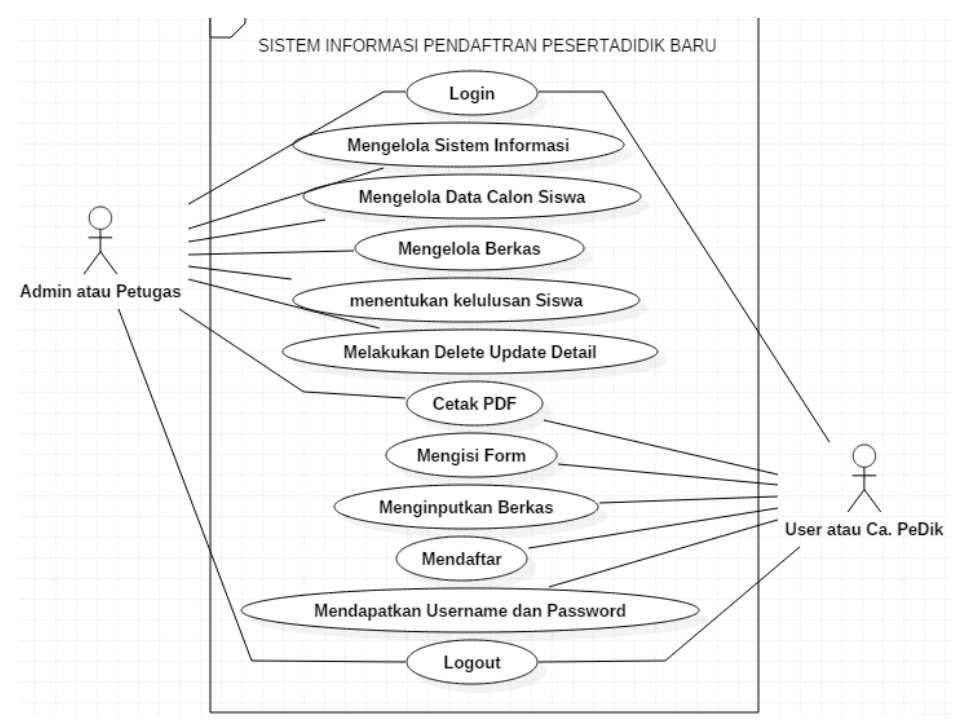

Figure 2. Use Case Diagram

b) Activity diagram

Figure 3 is an admin activity diagram. And picture 4 is the user activity diagram.

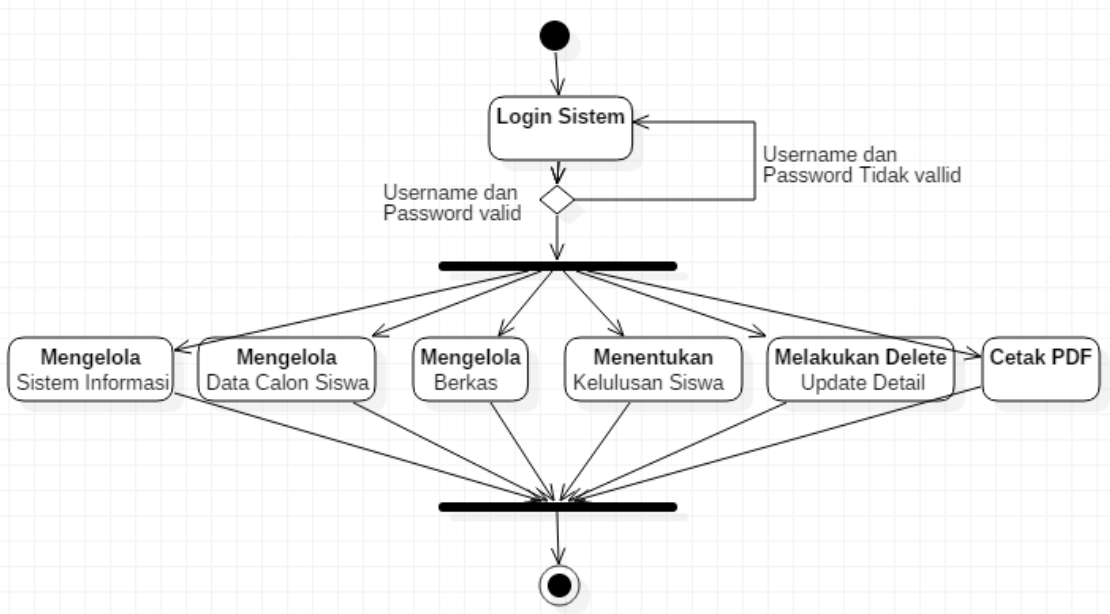

Figure 3. Admin Activity Diagram

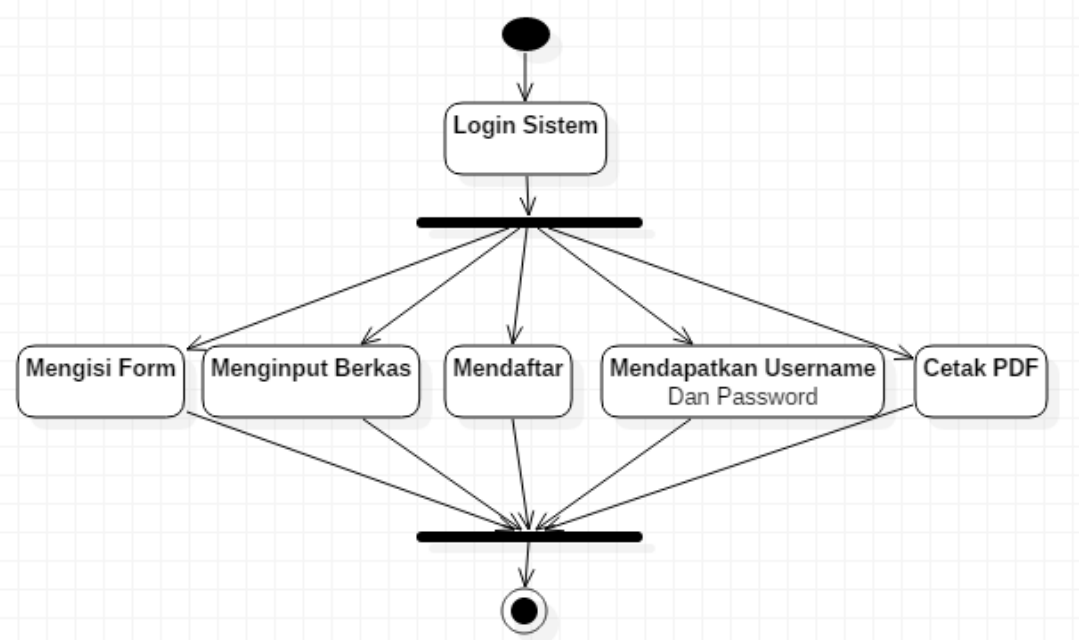

Figure 4. User Activity Diagram 
c) Sequence diagram

Figure 5 is a research sequence diagram.

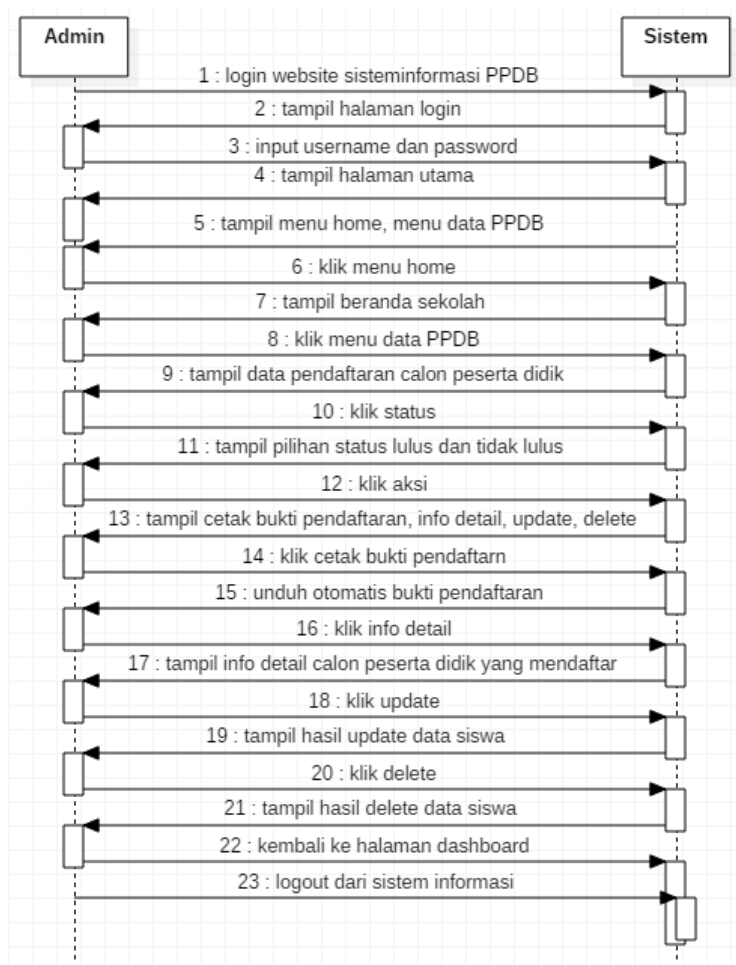

Figure 5. Sequence Diagram

\subsubsection{Detailed System Design}

a) Input Design

The input design consists of a login page in Figure 6, and a registration form page in Figure 7.

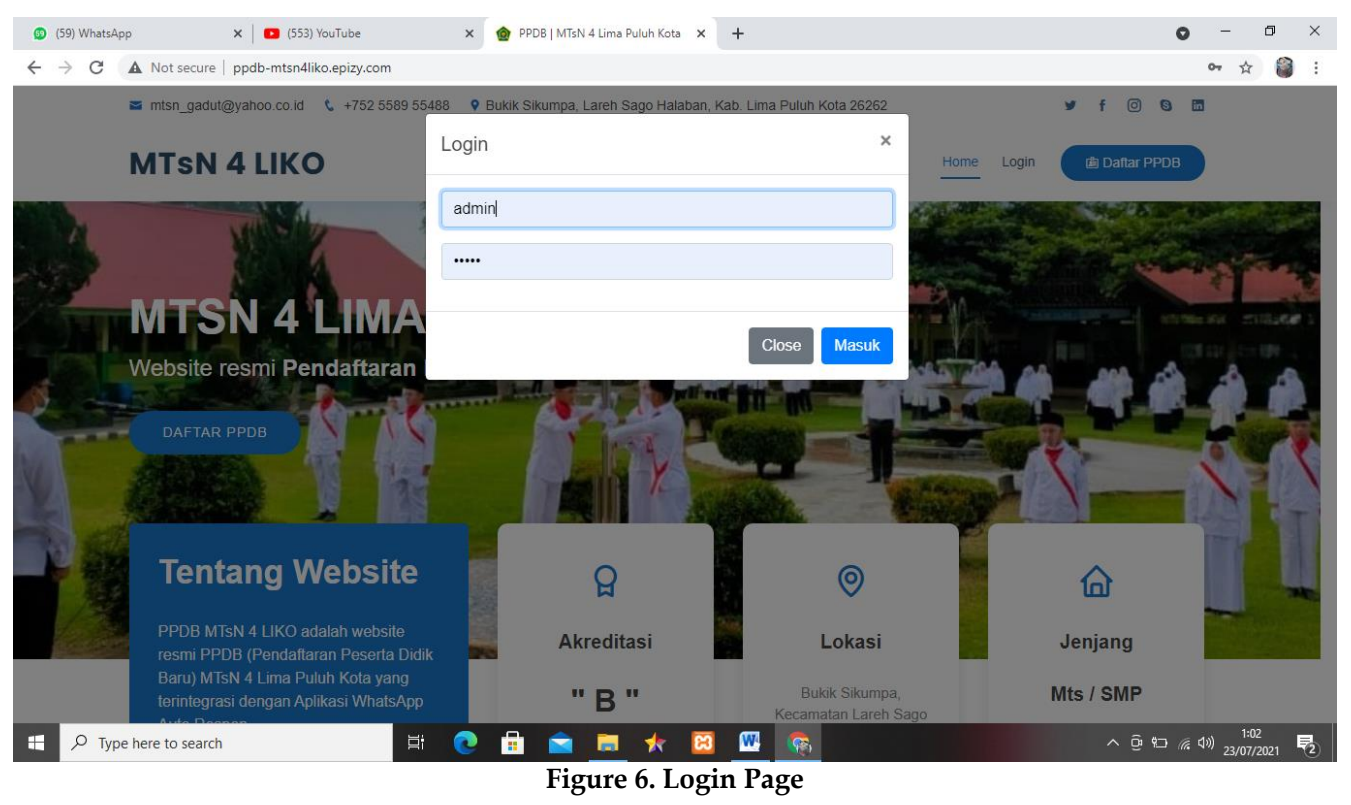




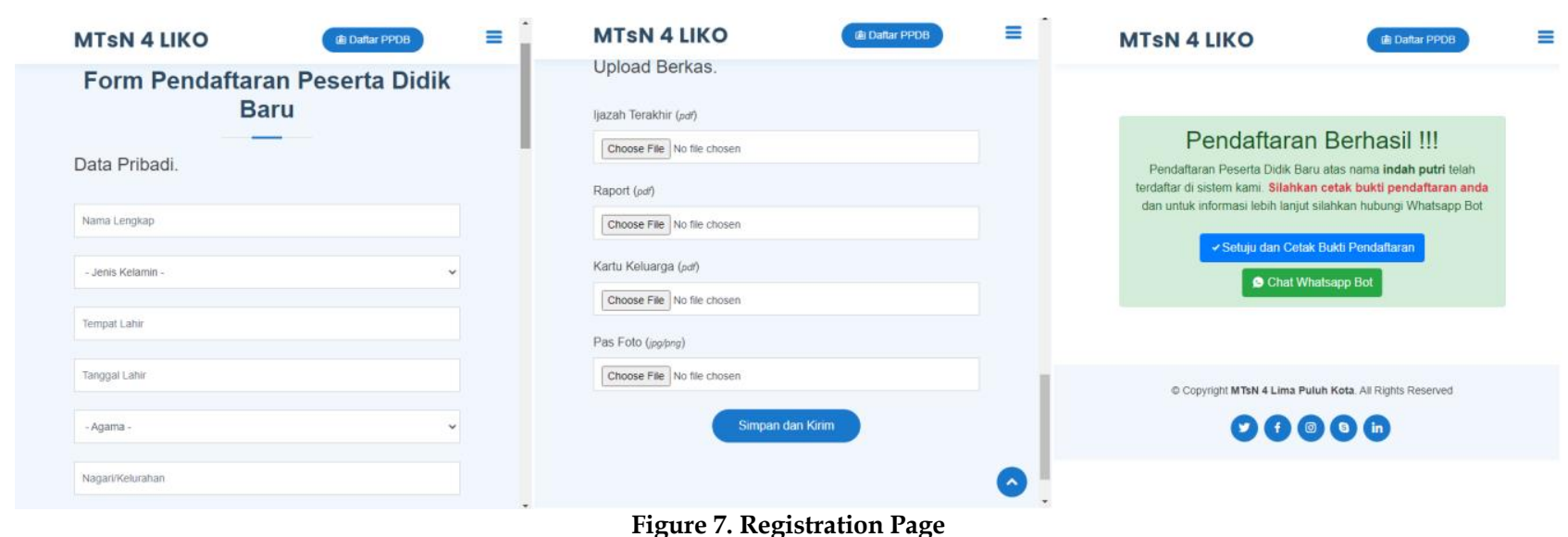

b) Output Design

The output design consists of proof of registration in Figure 8, a list of registered participants in Figure 9, graduation info in Figure 10, and a list of participants who passed in Figure 9.

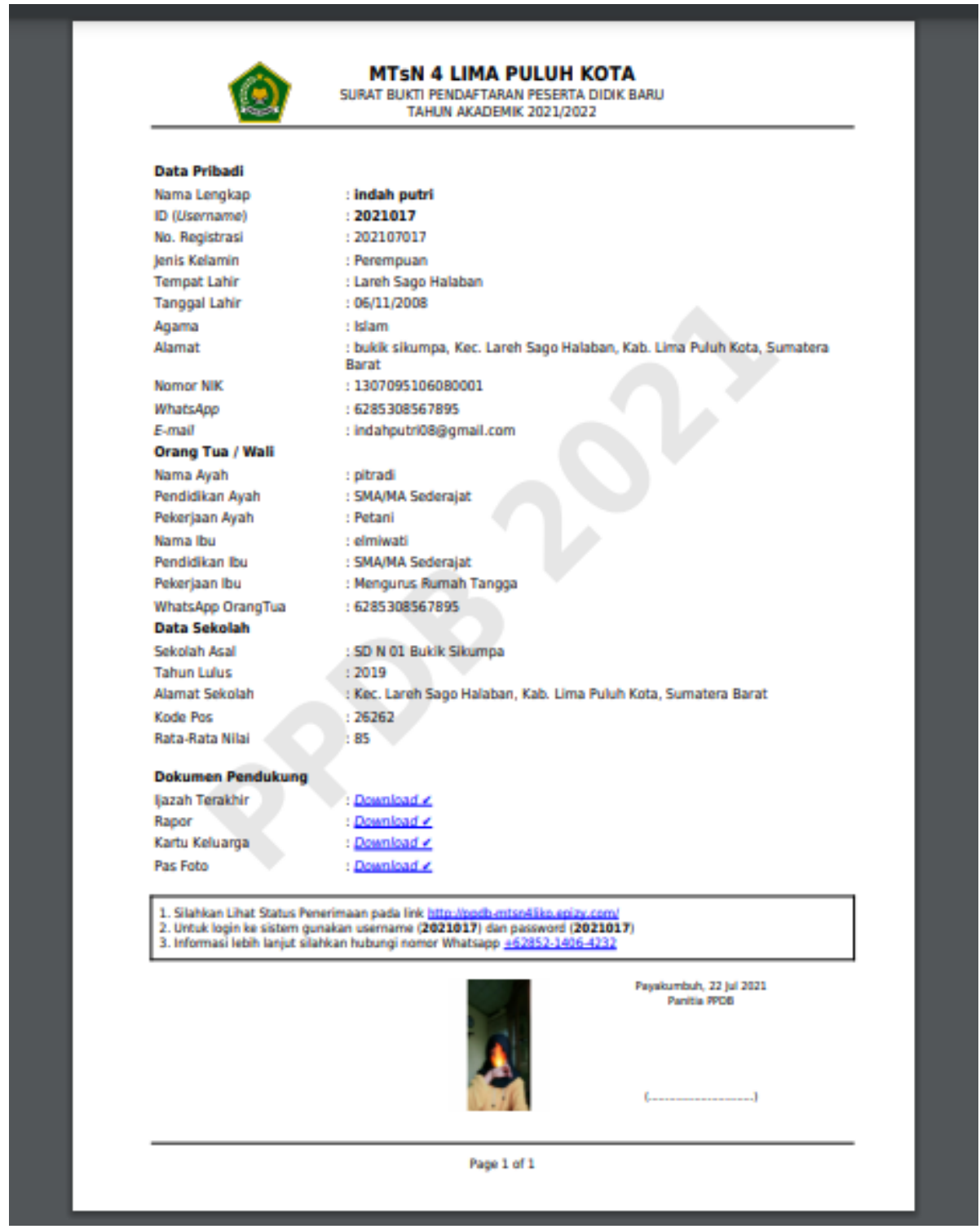

Figure 8. Proof of Registration 


\begin{tabular}{|c|c|c|c|c|}
\hline$\#$ & Nama & No. REG & Asal Sekolah & Status \\
\hline 1 & aditya zaky pratama & 202107007 & SD N 01 MUNGO & LULUS \\
\hline 2 & Artika Sari Devi & 202107006 & SD N 03 Labuah Gunuang & LULUS \\
\hline 3 & Hidyana & 202107014 & SD N 02 Amapalu & LULUS \\
\hline 4 & Keysa Kuntum Marwah & 202107013 & SD N 01 MUNGO & LULUS \\
\hline 5 & M. Aghif Ramdani & 202107009 & SD IT IPHI & LULUS \\
\hline 6 & Maulida Rahmi & 202107015 & SD N 05 Andaleh & LULUS \\
\hline 7 & Nurul putri suci hakim & 202107010 & SD N 8 MANDAU & LULUS \\
\hline 8 & Rara adinda putri & 202107008 & SD N 01 Bukik Sikumpa & LULUS \\
\hline 9 & Revi nahdatul qori'ah & 202107011 & SD N 04 LabuahGununag & LULUS \\
\hline 10 & safdsaf & 202107005 & fgds & Tidak Lulus \\
\hline 11 & yulia elsa & 202107016 & SD N 01 palembayan & Proses... \\
\hline 12 & Yusnia Hamid & 202107012 & SD N 01 Halaban & LULUS \\
\hline
\end{tabular}

Figure 9. List of Registered Participants

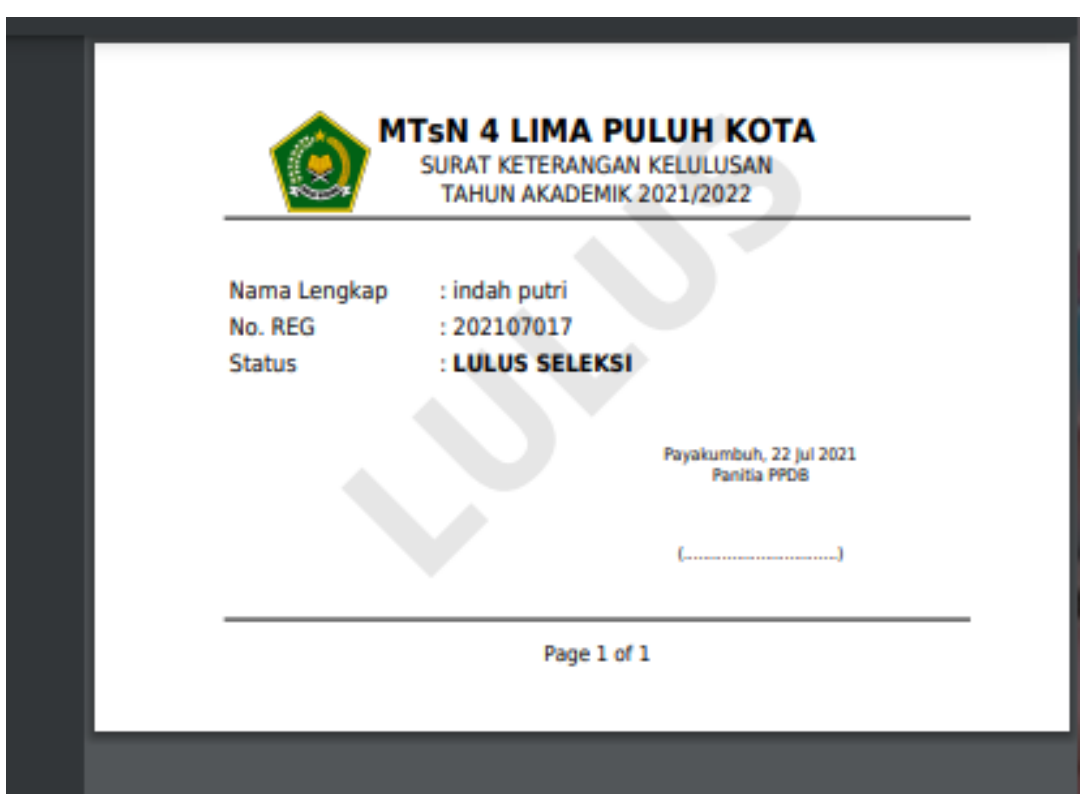

Figure 10. Graduation Information 


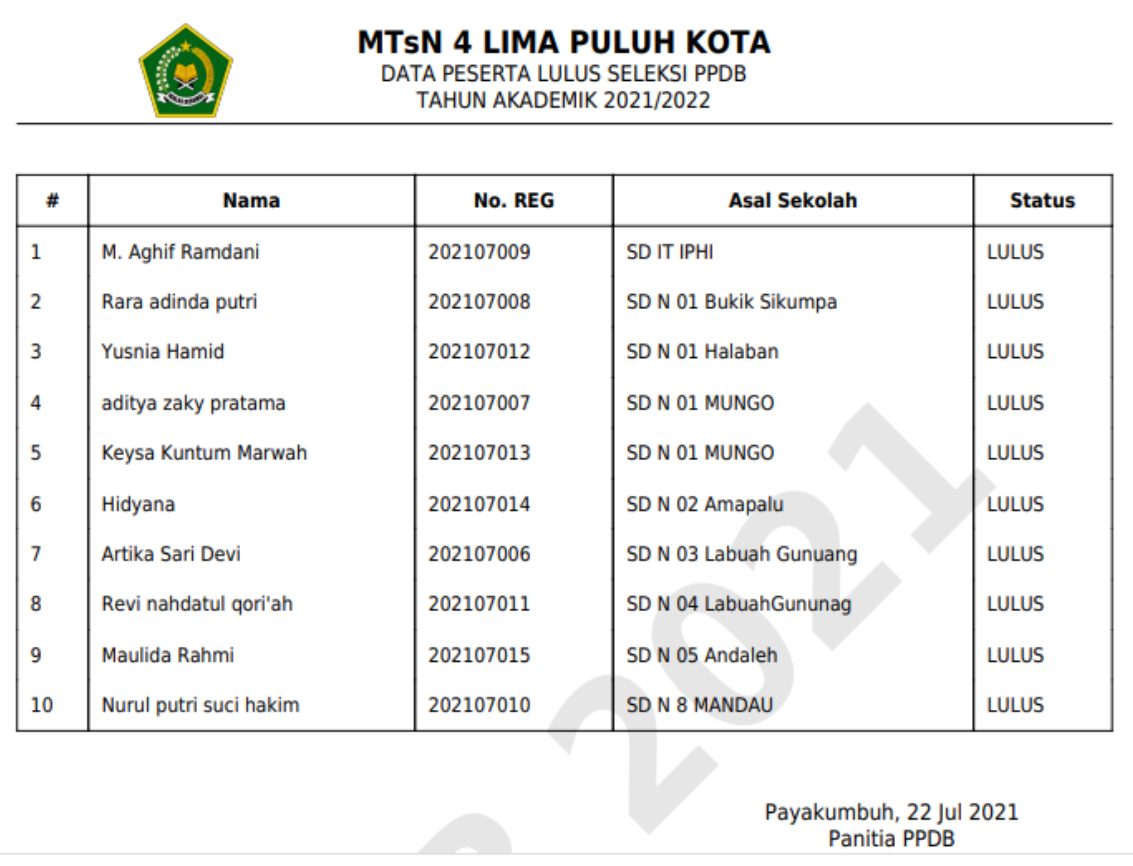

Figure 11. List of Graduates

\subsection{Disseminate}

This stage is the final activity of the research. In distributing the product, the author conducted socialization to MTsN 4 Kab. Lima Puluh Kota, and spread the PPDB web link to the school's WhatsApp group.

\subsection{Product Test}

\subsubsection{Validity test}

The results of the validity test that the author got were Valid with a value of 0.80 .

\subsubsection{Practical test}

The assessment results in general are very practical with a value of 93.33 .

\subsubsection{Effectiveness test}

The general assessment result is very high with a value of 0.91 .

\section{Conclusion}

Based on the explanation above and the results of the author's research regarding the design of the Android-based PPDB information system, it can be concluded that the method used to design this information system is the $4 \mathrm{D}$ version of the R\&D method using SDLC development. The programming language used is PHP/MySQL with supporting software VSCode and Framework CodeIgniter (CI) and other supporting software. This system can make it easier for officers to manage prospective students' data and make it easier for prospective students in the registration process. After testing the Android-based PPDB information system, the results of the validity test are 0.80 , the practicality test is 93.33 and the effectiveness test is 0.91 .

\section{References}

[1] S. Derta, "Penerimaan Santri Baru Online di MTI Canduang Menggunakan Bahasa Pemrograman Java Script dan PHP MySQL", 2018.

[2] M. B. Silva, “Tinajuan Umum Tentang Informasi Elektronik, Teknologi Elektronik, Transaksi Elektronik, 
Kebencian,dan Media Sosial," vol. 1, no. 9, pp. 1-11, 2016, doi: 10.1017/CBO9781107415324.004.

[3] D. Purwanti, I. Irawati, J. Adiwisastra, and H. Bekti, "Implementasi Kebijakan Penerimaan Peserta Didik Baru Berdasarkan Sistem Zonasi Di Kota Bandung," J. Governansi, vol. 5, no. 1, p. 12, 2019, doi: 10.30997/jgs.v5i1.1699.

[4] A. R. B. Irawan, M. Mardianto, and T. Khairunnisyah, "Implementasi Kebijakan Penerimaan Peserta Didik Baru (Ppdb) Berdasarkan Sistem Zonasi Di Smp Negeri 52 Palembang," 2019, [Online]. Available: https://repository.unsri.ac.id/28309/.

[5] R. A. Sundari and H. A. Musril, "Pengembangan Sistem Informasi Database Alumni ( Studi Kasus : SMAN $12 \times 11$ Enam Lingkung )," vol. 15, no. 2, pp. 115-124, 1858.

[6] M. . Darmawan and H. A. Musril, "Perancangan Sistem Pendaftaran Audiens Seminar Proposal di Institut Agama Islam Negeri ( IAIN ) Bukittinggi," vol. 11, pp. 26-39, 2021, doi: 10.34010/jati.v11i1.

[7] R. Okra and Y. Novera, "Pengembangan Media Pembelajaran Digital IPA Di SMP N 3 Kecamatan Pangkalan," J. Educ. J. Educ. Stud., vol. 4, no. 2, p. 121, 2019, doi: 10.30983/educative.v4i2.2340.

[8] S. Zakir and H. Wandi, "Aplikasi Sistem Pakar Penghitungan Zakat Maal Menggunakan PHP/MySQL 1Supratman," pp. 1-10, 2011.

[9] R. W. Qalbi and S. Derta, "Perancangan Aplikasi Monitoring Ibadah Harian Siswa Berbasis Android di SMAN 2 Tilatang Kamang," vol. 4221, pp. 1-12, 2020. 